\title{
The Phenomenon of Medical Waste Recycling in Indonesia: Contact Time and Chlorine Dose as a Disinfectant with the Bio-Indicator Bacillus subtilis and Bacillus stearothermophilus
}

\author{
Elanda Fikri ${ }^{1,2^{*}}$, lis Kurniati ${ }^{3}$, Wartiniyati ${ }^{4}$, Teguh Budi Prijanto ${ }^{2}$, \\ Pujiono ${ }^{2}$, Osman Syarief ${ }^{5}$, Amar Sharaf Eldin Khair ${ }^{6}$ \\ 1 Doctorate Program of Environmental Studies, Diponegoro University, Semarang, Indonesia \\ 2 Department of Environmental Health, Bandung Health Polytechnic, North Cimahi, Indonesia \\ 3 Medical Laboratory Technology, Bandung Health Polytechnic, Bandung \\ 4 Health Polytechnic of Jakarta II, Jakarta \\ 5 Department of Health Nutrition, Bandung Health Polytechnic, North Cimahi, Indonesia \\ 6 Omdurman Islamic University, Geography Department, Omdurman City, Sudan \\ * Corresponding author's email: elandafikri@yahoo.com
}

\begin{abstract}
Efforts that have been done to manage the Hazardous and Toxic waste into non-Hazardous and Toxic waste are done by emptying, shredding, washing, and rinsing at least 3 times and disinfecting using chlorine. This is in accordance with the Indonesian Regulation of Ministry of Health No. 27 of 2017, which has stated that surface cleaning is permitted to use $0.05 \%$ chlorine during the process. Furthermore, in the Indonesian Regulation of the Ministry of Environment and Forestry No.56 of 2015, the chemical disinfection process is permitted to use an additional 3-6\% sodium hypochlorite $(\mathrm{NaOCl})$. However, there are still differences in dosage and it has not been mentioned regarding the immersion period during the disinfection process on both of the regulations. The purpose of this study was to determine the difference in contact time and the dose of chlorine as a disinfectant on the number of Bacillus subtilis and Bacillus stearothermophilus in the medical waste recycling process. The research design used in this study was a Randomized Factorial Design with experimental research type. A total of 104 recyclable medical waste samples were taken, using 3 treatments and 6 repetitions. The average temperature of the chlorine solution at the contact time of 15 minutes, 30 minutes, and 45 minutes was $24.34{ }^{\circ} \mathrm{C} ; 24,53{ }^{\circ} \mathrm{C}$; and $24,54{ }^{\circ} \mathrm{C}$ respectively, while the average $\mathrm{pH}$ of the chlorine solution at the contact time of 15 minutes, 30 minutes, and 45 minutes was $8.344 ; 8,375$; and 8,461 respectively. The results showed that there was no difference in the duration of contact and the dose of chlorine as a disinfectant in the medical waste recycling process with a p-value of 0.377 . The percentage reduction in the number of Bacillus subtilis and Bacillus stearothermophilus before and after treatment was $99.99 \%$ based on 4 positive controls. The findings in this study were the duration of contact time and the effective dose used in the recycling process of medical waste, which was at a dosage of $0.03 \%$ with 45 minutes of contact time. The government needs to conduct a re-assessment regarding the recommended ideal dosage in the surface disinfection process so that it would not cause a potential risk to humans or the environment.
\end{abstract}

Keywords: recycling, medical waste, dosage, duration of contact, chlorine, disinfection.

\section{INTRODUCTION}

Hospital medical waste can be considered as a link in the chain of spreading infectious diseases. A dump of waste usually becomes a place for pathogenic organisms to accumulate and become a nest for insects and rodents. Moreover, the waste also contains various toxic chemicals and sharp objects that can cause health problems and injuries. Dust particles in the waste can cause air pollution which will cause disease and contaminate medical equipment and food (Adisasmito, 
2009; Akter and Trankler, 2003; Bokhoree, C. et al, 2014; Emilia et al, 2015).

Hazardous and Toxic Waste produced by health facilities is also referred to as medical waste (Windfeld and Brooks, 2015) and (Ministry of Environment and Forestry, 2018). The types of hazardous waste in health facilities include infectious properties, sharp materials, expired chemicals products, pathological substances, radioactive materials, pharmaceuticals products, cytotoxic properties, and medical equipment that have high heavy metal content (Indonesian Ministry of Environment and Forestry, 2015; Indonesian Ministry of Health, 2019; Mantzaras and Voudrias, 2017; Chartier et al., 2014; Manga et al., 2011).

In Indonesia, besides health facilities that have medical waste treatment facilities, most medical waste is handled by third parties. Based on data from the Ministry of Environment and Forestry in April 2020, the total capacity for medical waste treatment in Indonesia is 314.29 tons/day. In detail, there are as many as 21 provinces that provide health facilities that are capable of processing medical waste with a capacity of 70.21 tons per day and there are as many as 7 provinces that provide 7 Hazardous and Toxic waste treatment services with a capacity of 244.08 tons/day (Sinta Saptarina Soemarno, 2020).

Hospitals and other health installations have an "obligation to maintain" the environment and public health condition and have particular responsibilities related to the waste that is produced by the installations (Ojuolape and Afon, 2016; Omar et al, 2012). Among the obligations borne by these installations are the obligation to ensure that the handling, treatment, and disposal of the waste are done without causing any adverse health and environmental impacts (Akum, 2014; Al-Khatib, 2013; Ali et al, 2017). By implementing policies regarding health care waste management systems, medical facilities and research institutions are becoming closer to fulfilling the goal of creating a healthy and safe environment for their employees and the surrounding community (Ali et al, 2017).

Nowadays, there are still many hospitals that do not pay serious attention to their waste management system. The waste management system is still marginalized by the hospital management (Almuneef and Memish, 2003; Cheng et al, 2010). Based on the news from the Central Java Tribun newspaper, a case of selling jerry cans which have previously been used in the hemodialysis process was found out to be sold by the State Civil Apparatus at the Salatiga City Hospital. Indeed it is an effort to reduce medical waste, but it is not eligible for the existing regulatory procedures. The jerry cans are not being treated beforehand as to how Hazardous and Toxic Waste should be treated.

There should be proper and safe medical waste management, and the handling of solid medical waste must be immediately addressed to ensure the health and safety of workers and other people around the hospital (Bokhoree et al, 2014). Hence, a policy is required in accordance with The Occupational Health and Safety Management by carrying out management and monitoring activities of hospital medical waste as an important indicator that requires attention (Ali et al, 2017; Riyanto, 2013).

According to the Indonesian Ministry of Environment and Forestry No. P.56, 2015 Regarding Procedures and Technical Requirements for The Management of Hazardous and Toxic Waste from Health Service Facilities, based on article 38 , hospitals can carry out hazardous waste processing themselves, such as used Hazardous and Toxic waste packaging, used syringes, used infusion bottles other than blood infusions and/or body fluids; and/or used hemodialysis fluid packaging. Hazardous waste treatments are done by emptying, cleaning, disinfecting, and crushing or shredding. Hence, the result after the treatment is finally categorized into non-Hazardous and Toxic waste (Gunawan, 2019).

The processing process of Hazardous and Toxic waste into non-Hazardous and Toxic waste was carried out as a means of reducing the Hazardous and Toxic waste generated by the hospital (Gupta and Boojh, 2006; Hamid et al, 2013). However, there are still only a few of hospital that processes Hazardous and Toxic waste into non-Hazardous and Toxic waste, because based on the previous studies regarding medical waste management, including the research conducted by (Wulandari and Kusnoputranto, 2015), Dr. Soedirman Hospital still manages medical waste through the use of the container and doing things such as collection, sorting, transportation, storage, and processing.

One of the hospitals that have processed Hazardous and Toxic waste into non-Hazardous and Toxic waste is the Santo Borromeus Hospital. The management/minimization of hazardous and toxic waste activities are carried out by the Sanitation Installation of the St. Borromeus Hospital, 
as stated in the Regulation of the Indonesian Regulation of Ministry of Environment and Forestry No. P.56, 2015 in article 38, waste such as: used Hazardous and Toxic waste packaging, used infusion bottles other than blood and/or body fluids and used hemodialysis fluids. Among the three wastes, $50 \%$ of them was an infusion spike waste.

Efforts that have been done to manage the Hazardous and Toxic waste into non-Hazardous and Toxic waste are done by emptying, shredding, washing, and rinsing at least 3 times and disinfecting using chlorine. This is in accordance with the Indonesian Regulation of Ministry of Health No. 27 of 2017, which has stated that surface cleaning is permitted to use $0.05 \%$ chlorine during the process. Further, in the Indonesian Regulation of the Ministry of Environment and Forestry No.56 of 2015 , the chemical disinfection process is permitted to use an additional 3-6\% sodium hypochlorite $(\mathrm{NaOCl})$. However, there are still differences in dosage and it has not been mentioned regarding the immersion period during the disinfection process on both of the regulations.

\section{MATERIALS AND METHODS}

\section{Type of research}

The type of research used in this research is experimental design (Randomized Factorial Design), which is used to find out the effect of certain treatments towards others under controlled conditions. The research method uses the posttest design with control, which means that the researcher will carry out directly on a group of subjects with two conditions being implemented, as well as a comparison group. (Arikunto, 2010; Notoatmodjo, 2014)

\section{Sampling technique and sample size}

The sample in this study is the amount of recycled medical waste materials used for testing Bacillus subtilis and Bacillus stearothermophilus. The sample size taken in this study was based on the number of treatments and treatment repetitions used in the study. The treatments used in this study were 3 treatments using a comparison of contact time for 15 minutes, 30 minutes. and 45 minutes, as well as using doses of chlorine. The sample size calculation uses the Gomez formula (Sabri and Hastono, 2014), namely:

$$
\begin{gathered}
(t-1)(r-1) \geq 20 \\
(9-1)(r-1) \geq 20 \\
8 r-8 \geq 20 \\
8 r \geq 28 \\
\mathrm{r} \geq 3.5
\end{gathered}
$$

The number of repetitions in the study is 4 times, so the total sample in the study was 108 samples with 8 research control samples. The sampling technique in this study was carried out by grab sampling, the samples will be taken at certain times in one location and it is able to represent the entire medical waste material for the recycling process.

Research steps (Figures 1-4):

- Prepare a medical waste recycling reactor according to the dose and duration of contact time.

- Making the dosage (disinfectant solution) according to the required dose in the study.

- Inserting the medical waste recycle materials into the reactor

- Checking the required time (duration of contact) between the disinfectant solution and medical waste recyclable materials.

- Taking samples of each material for the $B a$ cillus subtilis and Bacillus stearothermophilus test in the medical waste recycling process.

- Conducting Laboratory Examination using Blood Agar and Soy Broth Trypticase.

\section{Bivariate analysis}

Bivariate analysis was carried out on variables that were thought to be related or had an influence and by seeing the influence magnitude of the independent variable towards the dependent variable. The bivariate analysis used in this study was two-way ANOVA.

\section{RESULTS AND DISCUSSION}

Temperature measurement result after the given treatment shown in Table 1. Based on these results at each contact time and the dose of chlorine in the medical waste recycling process, the average temperature of the chlorine solution at the contact time of 15 minutes, 30 minutes, and 45 minutes was $24.34{ }^{\circ} \mathrm{C} ; 24,53^{\circ} \mathrm{C}$; and $24.54^{\circ} \mathrm{C}$.

The temperature of the chlorine solution during the experiment did not show a significant increase or decrease in its temperature. The temperature range at the time of the study was 


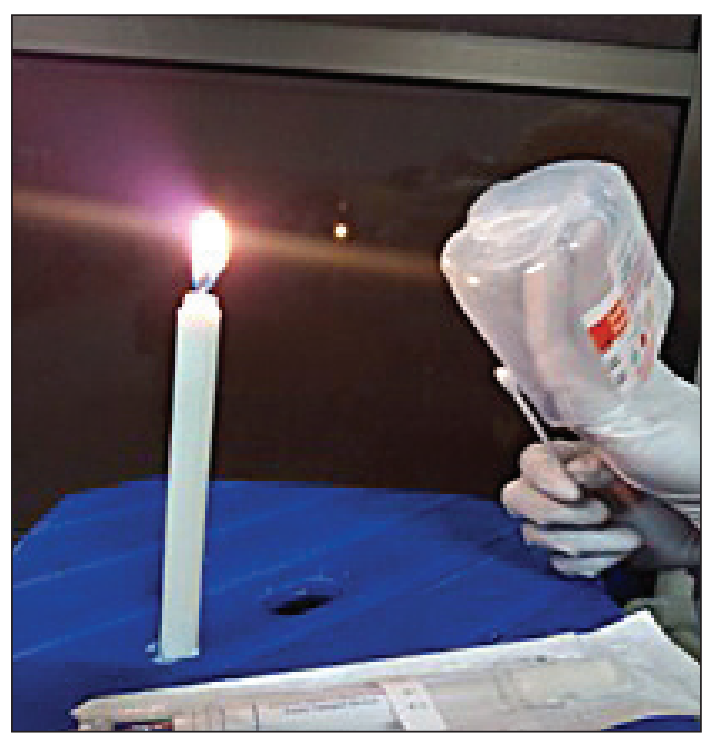

Figure 1. Aseptic technique during the swabbing process of used spike infusion

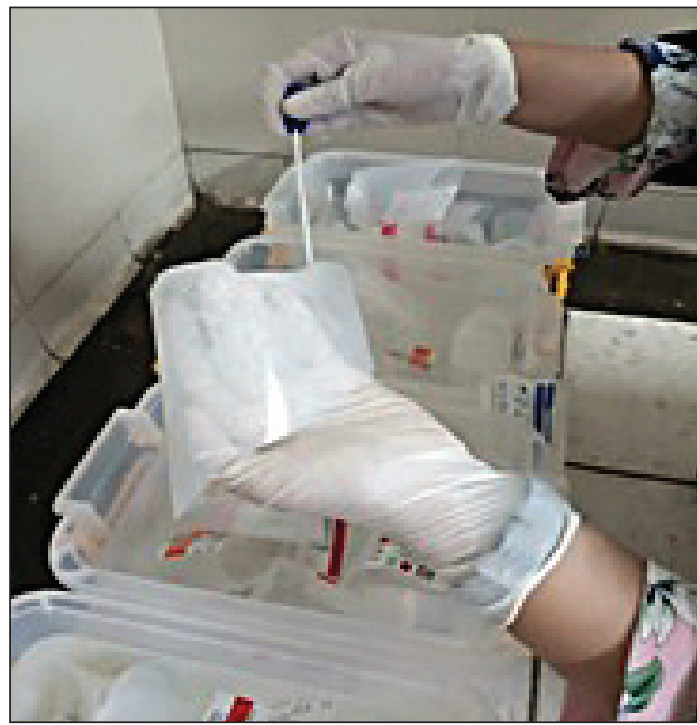

Figure 3. Used spike infusion swabbing process

$22.8^{8}-26.6^{\circ} \mathrm{C}$. Changes in temperature at any time in the reactor can be affected due to changes in air temperature around the research area. According to Soebagio (2011) in Handayani and Sugeng (2015), states that the higher water temperature can increase the effectiveness of chlorine for disinfection. This condition also affects the amount of chlorine for disinfection, when the water temperature decreases, the use of required chlorine increases, and when the temperature increases the use of chlorine is relatively less.

However, Sari's research, 2018 states that the higher the water temperature, the greater the chlorine decay. If the water temperature increases, it

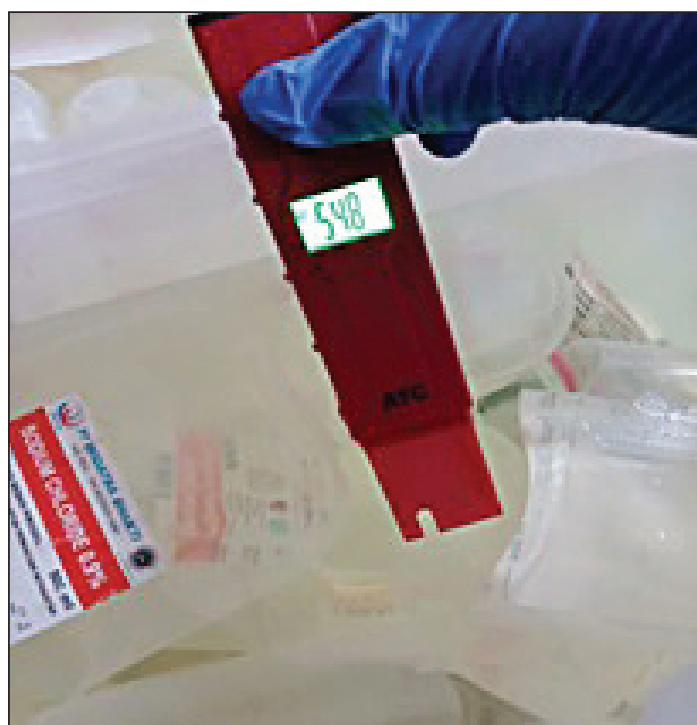

Figure 2. Measurement of temperature and $\mathrm{Ph}$ during the medical waste recycling process

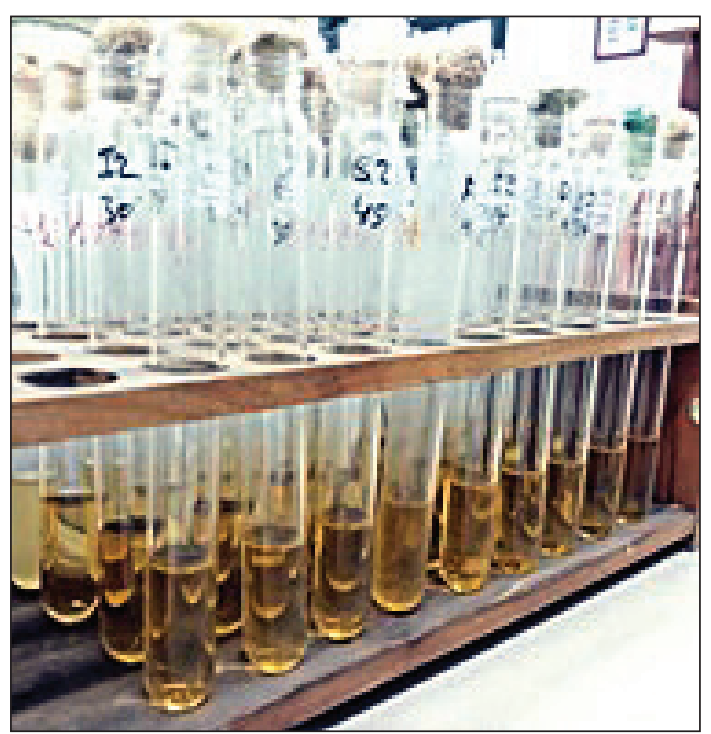

Figure 4. Bacterial culture/microbial isolation from samples of recyclable medical waste

will affect the presence of calcium hypochlorite, the efficiency of calcium hypochlorite will decrease as the water temperature increases. Parameter $\mathrm{pH}$ measurement results after the given treatment shown in Table 2.

Based on the results of $\mathrm{pH}$ measurements at each contact time and the dose of chlorine in the medical waste recycling process, the average $\mathrm{pH}$ of the chlorine solution at the contact time of 15 minutes, 30 minutes, and 45 minutes was 8.344 ; 8,375 ; and 8,461 . It can be seen that the $\mathrm{pH}$ of the chlorine solution at each concentration has increased. The greater the concentration or dose of chlorine used, the $\mathrm{pH}$ will increase or the solution 
Table 1. Temperature measurement result after the given treatment

\begin{tabular}{|c|c|c|c|c|}
\hline \multirow{2}{*}{ Chlorine dosage } & \multirow{2}{*}{ Repetition } & \multicolumn{3}{|c|}{ Temperature $\left({ }^{\circ} \mathrm{C}\right)$} \\
\hline & & 15 minutes & 30 minutes & 45 minutes \\
\hline \multirow{4}{*}{$0.03 \%$} & 1 & 25.6 & 25.8 & 25.9 \\
\hline & 2 & 23.3 & 23.5 & 24 \\
\hline & 3 & 26.6 & 26.5 & 26.6 \\
\hline & 4 & 23.6 & 23.8 & 23.8 \\
\hline \multirow{4}{*}{$0.05 \%$} & 1 & 25.7 & 25.9 & 26.1 \\
\hline & 2 & 23.2 & 23.5 & 23.6 \\
\hline & 3 & 25.7 & 25.7 & 25.6 \\
\hline & 4 & 23.6 & 23.7 & 23.8 \\
\hline \multirow{4}{*}{$0.07 \%$} & 1 & 25.8 & 25.9 & 26.1 \\
\hline & 2 & 23.3 & 23.4 & 23.5 \\
\hline & 3 & 25.7 & 25.8 & 25.8 \\
\hline & 4 & 23.2 & 23.4 & 23.8 \\
\hline \multirow{4}{*}{$0.3 \%$} & 1 & 25.8 & 25.7 & 25.8 \\
\hline & 2 & 23.1 & 23.6 & 23.4 \\
\hline & 3 & 24.4 & 24.8 & 24.9 \\
\hline & 4 & 23.2 & 23.6 & 23.9 \\
\hline \multirow{4}{*}{$0.5 \%$} & 1 & 25.6 & 25.9 & 25.7 \\
\hline & 2 & 22.8 & 23.5 & 23.5 \\
\hline & 3 & 24.3 & 24.7 & 25 \\
\hline & 4 & 23.2 & 23.4 & 23.6 \\
\hline \multirow{4}{*}{$0.7 \%$} & 1 & 25.6 & 25.7 & 25.6 \\
\hline & 2 & 22.9 & 23.2 & 23.5 \\
\hline & 3 & 24.7 & 25.2 & 25.1 \\
\hline & 4 & 23.4 & 23.8 & 23.5 \\
\hline \multirow{4}{*}{$3 \%$} & 1 & 25.7 & 25.6 & 25.6 \\
\hline & 2 & 23 & 23.2 & 23.5 \\
\hline & 3 & 24.7 & 25.1 & 25.2 \\
\hline & 4 & 23.2 & 23.6 & 23.5 \\
\hline \multirow{4}{*}{$5 \%$} & 1 & 25.5 & 25.3 & 24.9 \\
\hline & 2 & 23.7 & 23.7 & 23.2 \\
\hline & 3 & 24.5 & 24.8 & 24.9 \\
\hline & 4 & 23.3 & 23.5 & 23.6 \\
\hline \multirow{4}{*}{$7 \%$} & 1 & 25.5 & 25.3 & 25.0 \\
\hline & 2 & 24.1 & 24.1 & 23.2 \\
\hline & 3 & 24.6 & 25 & 25 \\
\hline & 4 & 24.2 & 23.9 & 23.9 \\
\hline \multicolumn{2}{|c|}{ Average $(\mathrm{N}=108)$} & 24.342 & 24.531 & 24.544 \\
\hline \multicolumn{2}{|c|}{ Standard Deviation } & 1.1284 & 1.0362 & 1.0338 \\
\hline \multicolumn{2}{|c|}{ Maximum } & 26.6 & 26.5 & 26.6 \\
\hline \multicolumn{2}{|c|}{ Minimum } & 22.8 & 23.2 & 23.2 \\
\hline
\end{tabular}

becomes more alkaline. This is because if the chlorine $\mathrm{Ca}(\mathrm{OCl})_{2}$ is in water, hence the following reaction will occur:

$$
\mathrm{Ca}(\mathrm{OCl})_{2}+2\left(\mathrm{H}_{2} \mathrm{O}\right) \leftrightarrow 2 \mathrm{HOCl}+\mathrm{Ca}(\mathrm{OH})_{2}
$$

The reaction of chlorine with water will cause an increase in the $\mathrm{pH}$ of the water because it produces $\mathrm{Ca}(\mathrm{OH})_{2}$ which is an alkaline or strong base and $\mathrm{HOCl}$ which is a weak acid. $\mathrm{Ca}(\mathrm{OH})_{2}$ immediately decomposes to form $\mathrm{Ca}^{2+}$ and $\mathrm{OH}^{-}$ ions so that the ratio of $\mathrm{OH}$ ions ${ }^{-}$is greater than $\mathrm{H}_{\text {ions }}^{+}$which causes the solution to be alkaline. $\mathrm{HOCl}$ is the remaining free chlorine which is most effective as a disinfectant compared to $\mathrm{OCl}^{-}$ which is produced as free chlorine from the use of $\mathrm{NaOCl}$ and $\mathrm{Cl}$ disinfectants in the form of gas (Aziz et al., 2013). Residual chlorine measurement result shown in Table 3. 
Table 2. $\mathrm{pH}$ measurement results after the given treatment

\begin{tabular}{|c|c|c|c|c|}
\hline \multirow{2}{*}{ Chlorine dosage } & \multirow{2}{*}{ Repetition } & \multicolumn{3}{|c|}{$\mathrm{pH}$} \\
\hline & & 15 minutes & 30 minutes & 45 minutes \\
\hline \multirow{4}{*}{$0.03 \%$} & 1 & 8 & 8 & 8 \\
\hline & 2 & 8.2 & 8.3 & 8.4 \\
\hline & 3 & 7.7 & 7.7 & 7.7 \\
\hline & 4 & 7.6 & 7.7 & 7.7 \\
\hline \multicolumn{2}{|c|}{ Average $(\mathrm{N}=12)$} & 7.950 & 7.875 & 7.875 \\
\hline \multirow{4}{*}{$0.05 \%$} & 1 & 8 & 8 & 8 \\
\hline & 2 & 8.3 & 8.3 & 8.4 \\
\hline & 3 & 7.7 & 7.7 & 7.7 \\
\hline & 4 & 7.6 & 7.7 & 7.7 \\
\hline \multicolumn{2}{|c|}{$(\mathrm{N}=12)$} & 7.950 & 7.9 & 7.9 \\
\hline \multirow{4}{*}{$0.07 \%$} & 1 & 8 & 8 & 8 \\
\hline & 2 & 8.2 & 8.3 & 8.4 \\
\hline & 3 & 7.7 & 7.7 & 7.8 \\
\hline & 4 & 7.7 & 7.7 & 7.7 \\
\hline \multicolumn{2}{|c|}{ Average $(\mathrm{N}=12)$} & 7.975 & 7.9 & 7.9 \\
\hline \multirow{4}{*}{$0.3 \%$} & 1 & 9 & 9 & 9 \\
\hline & 2 & 8.5 & 8.6 & 8.6 \\
\hline & 3 & 7.9 & 7.9 & 7.9 \\
\hline & 4 & 7.6 & 7.6 & 7.6 \\
\hline \multicolumn{2}{|c|}{ Average $(\mathrm{N}=12)$} & 8.725 & 8.25 & 8.25 \\
\hline \multirow{4}{*}{$0.5 \%$} & 1 & 9 & 9 & 9 \\
\hline & 2 & 8.4 & 8.6 & 8.7 \\
\hline & 3 & 8 & 8 & 8 \\
\hline & 4 & 7.6 & 7.6 & 7.6 \\
\hline \multicolumn{2}{|c|}{ Average $(\mathrm{N}=12)$} & 8.325 & 8.25 & 8.25 \\
\hline \multirow{4}{*}{$0.7 \%$} & 1 & 9 & 9 & 10 \\
\hline & 2 & 8.7 & 8.7 & 8.8 \\
\hline & 3 & 8 & 8 & 8.1 \\
\hline & 4 & 7.6 & 7.7 & 7.7 \\
\hline \multicolumn{2}{|c|}{ Average $(\mathrm{N}=12)$} & 8.65 & 8.325 & 8.325 \\
\hline \multirow{4}{*}{$3 \%$} & 1 & 9 & 9 & 10 \\
\hline & 2 & 9 & 9 & 9.1 \\
\hline & 3 & 8.2 & 8.3 & 8.3 \\
\hline & 4 & 7.7 & 7.7 & 7.7 \\
\hline \multicolumn{2}{|c|}{ Average $(\mathrm{N}=12)$} & 8.775 & 8.475 & 8.475 \\
\hline \multirow{4}{*}{$5 \%$} & 1 & 10 & 10 & 10 \\
\hline & 2 & 9.5 & 9.5 & 9.5 \\
\hline & 3 & 8.5 & 8.5 & 8.6 \\
\hline & 4 & 7.8 & 7.8 & 7.9 \\
\hline \multicolumn{2}{|c|}{ Average $(\mathrm{N}=12)$} & 9 & 8.95 & 8.95 \\
\hline \multirow{4}{*}{$7 \%$} & 1 & 10 & 10 & 10 \\
\hline & 2 & 10 & 10.1 & 10.2 \\
\hline & 3 & 8.8 & 8.8 & 8.8 \\
\hline & 4 & 7.9 & 8 & 8 \\
\hline \multicolumn{2}{|c|}{ Average $(\mathrm{N}=12)$} & 9.175 & 9.225 & 9.25 \\
\hline & & 8.344 & 8.375 & 8.461 \\
\hline Star & tion & 0.7229 & 0.7201 & 0.8058 \\
\hline & & 10 & 10.1 & 10.2 \\
\hline & & 7.6 & 7.6 & 7.6 \\
\hline
\end{tabular}


Table 3. Chlorine residual measurement results data at doses of $0.05 \%$ and $0.5 \%$

\begin{tabular}{|c|c|c|}
\hline \multirow{3}{*}{ Chlorine dosage } & \multirow{2}{*}{ Repetition } & Residual chlorine (\%) \\
\cline { 2 - 3 } & & 45 Minutes \\
\hline \multirow{3}{*}{$0.05 \%$} & 1 & - \\
\cline { 2 - 3 } & 2 & 0.03 \\
\cline { 2 - 3 } & 3 & 0.03 \\
\cline { 2 - 3 } & 4 & 0.02 \\
\hline \multirow{3}{*}{$0.5 \%$} & 1 & - \\
\cline { 2 - 3 } & 2 & 0.49 \\
\cline { 2 - 3 } & 3 & 0.49 \\
\cline { 2 - 3 } & 4 & 0.41 \\
\hline
\end{tabular}

In addition to temperature and $\mathrm{pH}$ factors, the effectiveness of the disinfection process is also influenced by residual chlorine. Following are the results of measuring the residual chlorine content for 4 consecutive days. The examination of the chlorine content at a concentration of $0.05 \%$ and $0.5 \%$. The chlorine content in the two concentration variations decreased with each repetition. The chlorine concentration of $0.05 \%$ decreased to $0.03 \%$ on the 2 nd repetition, and the $3 \mathrm{rd}$ and $0.02 \%$ on the 4 th repetition. While the chlorine concentration of $0.5 \%$ decreased to $0.49 \%$ in the 2nd and 3rd repetitions, then decreased again in the 4 th repetition to $0.41 \%$. The decrease in chlorine levels in this study can be influenced by several factors, including temperature and water $\mathrm{pH}$. According to Sari's research (2018), the higher the temperature, the greater the chlorine decay. In the results of temperature measurement, it was found that the longer the contact time, the temperature of the chlorine solution in the reactor increased so that the chlorine decay process was getting faster causing the chlorine level to decrease. So that if

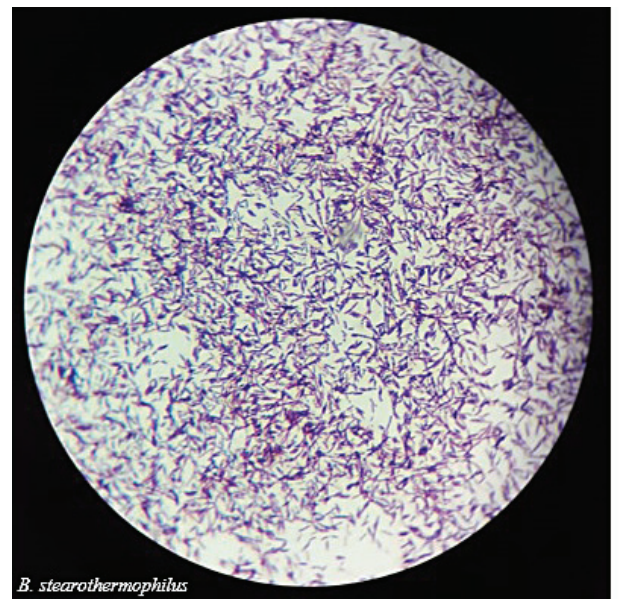

the chlorine level decreases, the effectiveness of disinfection will also decrease.

In addition, the reduction in residual chlorine is also influenced by the duration of water storage time. During the chlorination process, the chlorine will be reduced to chloride (pure $\mathrm{Cl}$ ) which has no killing power at all (Giyantini, 2004 in Anam). The longer the water storage time, the more chlorine residual is reduced into chloride. Measurement of residual chlorine carried out in the 2 nd to 4 th repetitions of 45 minutes contact time showed that the residual chlorine had decreased, meaning that the chlorine was reduced into chloride.

\section{Total plate count of Bacillus sp. test result}

Figure 5 shows Bacillus sp. found in the medical waste recycling process, viewed on a microscope with $1000 \times$ magnification. Bacillus $s p$ with shape: round, size: $1-8 \mathrm{~mm}$ diameter, pigment: white-gray-greenish, elevation: flat/slightly convex, property: haemolysis, surface: rough-dry, and margin: serrated. The colony of the suspect Bacillus sp. was grown on biochemical test media, namely semi-solid, glucose, mannitol, arabinose, gelatin, nitrite, urea, and Simmons' citrate, continued by incubating at $37^{\circ} \mathrm{C}$ for $18-24$ hours, and then observing the reaction results in the biochemical test, and lastly was to determine the bacterial species.

In this study, the treatment given was in the form of nine variations of chlorine/ chlorine concentration and three variations of contact time. 138 samples were taken and examined from 4 repetitions. The existing quality standards related to the presence of Bacillus sp. Spore was stated in the Indonesian Regulation of Minister of Environment

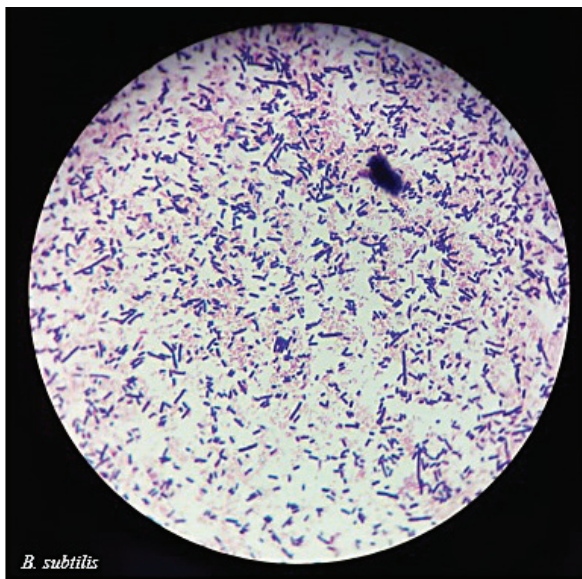

Figure 5. Bacillus sp. 
Table 4. Total plate count of Bacillus sp. (Bacillus subtilis and Bacillus stearothermophilus) test result

\begin{tabular}{|c|c|c|l|l|}
\hline No & Sample code & TPC test result & Unit & \multicolumn{1}{|c|}{ Description } \\
\hline 1 & C. A & $67 \times 10^{5}$ & CFU $/ \mathrm{ml}$ & Bacillus stearothermophilus \\
\hline 2 & B. $45^{\prime}$ & 300 & CFU $/ \mathrm{ml}$ & Bacillus subtilis \\
\hline 3 & C. B & $>300 \times 10^{5}$ & CFU $/ \mathrm{ml}$ & Bacillus stearothermophilus \\
\hline 4 & C. $30^{\prime}$ & 100 & CFU $/ \mathrm{ml}$ & Bacillus subtilis \\
\hline 5 & C. $30^{\prime}$ & $47 \times 10^{4}$ & CFU $/ \mathrm{ml}$ & Bacillus stearothermophilus \\
\hline 6 & C. $45^{\prime}$ & 10 & CFU $/ \mathrm{ml}$ & Bacillus stearothermophilus \\
\hline 7 & C. C & $>300 \times 10^{5}$ & CFU $/ \mathrm{ml}$ & Bacillus subtilis \\
\hline 8 & D. $45^{\prime}$ & 100 & CFU $/ \mathrm{ml}$ & Bacillus subtilis \\
\hline 9 & F3. $15^{\prime}$ & $1 \times 10^{4}$ & CFU $/ \mathrm{ml}$ & Bacillus stearothermophilus \\
\hline 10 & F4. $30^{\prime}$ & negative & CFU $/ \mathrm{ml}$ & \\
\hline 11 & F4. $45^{\prime}$ & negative & CFU $/ \mathrm{ml}$ & \\
\hline 12 & G. $15^{\prime}$ & negative & CFU $/ \mathrm{ml}$ & \\
\hline 13 & C. G & $50 \times 10^{5}$ & CFU $/ \mathrm{ml}$ & Bacillus subtilis \\
\hline 14 & H. $30^{\prime}$ & 1000 & CFU $/ \mathrm{ml}$ & Bacillus stearothermophilus \\
\hline 15 & H3. $30^{\prime}$ & 1000 & CFU $/ \mathrm{ml}$ & Bacillus stearothermophilus \\
\hline 16 & I. $30^{\prime}$ & 100 & CFU $/ \mathrm{ml}$ & Bacillus subtilis \\
\hline 17 & C. I & $>300 \times 10^{5}$ & CFU $/ \mathrm{ml}$ & Bacillus subtilis \\
\hline
\end{tabular}

and Forestry No. P.56, 2015 concerning Procedures and Technical Requirements for Management of Hazardous and Toxic Waste from Health Care Facilities, as a concentration of $1 \times 10^{4}$.

In Table 4, there are 14 positive samples of Bacillus sp, and there are 3 (three) negative samples of Bacillus sp. The presence of Bacillus $\mathrm{sp}$. in medical waste treatment is a bioindicator of the success or failure of the disinfection process. The number of TPC on Control A (CA), $\mathrm{CB}, \mathrm{CC}, \mathrm{CG}$, and $\mathrm{CI}$ exceeds the requirements on The Indonesian Regulation of Minister of Environment and Forestry No. P.56, 2015 concerning Procedures and Technical Requirements for Management of Hazardous and Toxic Waste from Health Service Facilities, which exceeds the concentration of $1 \times 10^{4} .14$ samples were positive for Bacillus sp. with a minimum value at a concentration of $1 \times 10^{1}$ and a maximum of $47 \times 10^{4}$, meaning that the 8 samples that were positive for Bacillus sp, was still below the required quality standard, while one positive sample of Bacillus sp. did not meet the requirements on the 3 rd repetition, namely at a concentration of $0.07 \%$ and a contact time of 30 minutes.

\section{Normality test}

In Table 5 the output results of the normality test indicated. Based on these results, it was found that Kolmogorov Smirnov's p-value was 0.001. The analysis conditions are if the $\mathrm{p}$-value $>\alpha(0.05)$ then the data is normally distributed or $\mathrm{H} 0$ is rejected. In the table, the p-value results for the number of Bacillus sp. is smaller than $\alpha(0.05)$ thus, it is categorized that the data is not normally distributed or $\mathrm{H} 0$ is accepted. If the data is not homogeneous, then a non-parametric analysis is carried out.

\section{Homogeneity test}

Table 6 show the output results of the homogeneity test. Based on these results it was found that the $p$-value was 0.001 . The analysis conditions are if the $p$-value $>\alpha(0.05)$ then the data is homogeneous or $\mathrm{H} 0$ is rejected. In table 6 , the pvalue for the number of Bacillus sp. obtained are smaller than $\alpha(0.05)$ thus, the data is categorized as not homogeneous or $\mathrm{H} 0$ is accepted. If the data is not homogeneous, then a non-parametric analysis is carried out.

Table 5. Normality test results

\begin{tabular}{|c|c|c|c|}
\hline \multirow{2}{*}{ No } & \multirow{2}{*}{ Variation } & Kolmogorov-Smirnov test & Shapiro-Wilk test \\
\cline { 3 - 4 } & & \multicolumn{2}{|c|}{ p-Value } \\
\hline 1 & 15 minutes & 0.001 & 0.001 \\
\hline 2 & 30 minutes & 0.001 & 0.001 \\
\hline 3 & 45 minutes & 0.001 & 0.001 \\
\hline
\end{tabular}


Table 6. Homogeneity test results

\begin{tabular}{|c|c|c|c|}
\hline Levene Statistic & df1 & df2 & Sig. \\
\hline 4.808 & 26 & 81 & 0.001 \\
\hline
\end{tabular}

\section{Bivariate data analysis}

Bivariate analysis used the Kruskal-Wallis test because the test results showed that the data were not normally distributed. The test in this study was to determine the difference in the duration of contact time and the dose of chlorine as a disinfectant against the number of Bacillus subtilis and Bacillus stearothermophilus in the medical waste recycling process. The output results of the Kruskal-Wallis test show Table 7.

In the Table 7, the p-value is 0.377 consecutively. The analysis conditions are if the p-value $<\alpha(0.05)$ then HO is rejected or the variable is said to have a significant difference. The $\mathrm{p}$-value is $0.377>0.05$, it can be concluded that $\mathrm{H} 0$ is accepted, which means there is no difference in the duration of contact time and the dose of chlorine as a disinfectant on the number of Bacillus subtilis and Bacillus stearothermophilus in the medical waste recycling process.

The results of the bivariate statistical test showed that there was no difference in the duration of contact time and the dose of chlorine as a disinfectant on the number of Bacillus subtilis and Bacillus stearothermophilus in the medical waste recycling process. However, descriptively, on the three-contact time at a chlorine concentration of $0.03 \%$, there was no Bacillus sp found. While the smallest average number of Bacillus sp TPC is found in the contact time of 45 minutes namely 15,185 . If the results are viewed as descriptive analysis, then from this study it can

Table 7. Kruskal-Wallis test results

\begin{tabular}{|c|c|}
\hline Statistic & Total of Bacillus sp. \\
\hline Chi-Square & 8.597 \\
\hline Df & 8 \\
\hline Sig & 0.377 \\
\hline
\end{tabular}

be concluded that the effective concentration of chlorine as a disinfectant in the recycling process of medical waste is on a concentration of $0.03 \%$ with an effective contact time of 45 minutes.

\section{Minimum bactericidal concentration test result}

Based on Table 8 it is known that the Minimum Bactericidal Concentration (MBC) for $\mathrm{Ba}$ cillus stearothermophilus is at a concentration of $0.03 \%$ in 45 minutes, and for Bacillus subtilis at $0.03 \%$ in 30 minutes and 45 minutes. Thus, on further tests to determine the $\mathrm{MBC}$ in these two bacteria, for a while it can be concluded that the most effective concentration is at $0.03 \%$ with 45 minutes contact time $(0 \mathrm{CFU} / \mathrm{ml})$.

\section{The working mechanism of chlorine as a disinfectant in the recycling process of medical waste}

Chlorine or calcium hypochlorite is a type of disinfectant used in the management or recycling of medical waste in hospitals. The alternative choice of using chlorine as a disinfectant is because it is easy to find, it has a cheap price and relatively more stable and can be stored longer. If chlorine is dissolved in water it will produce the following reaction:

$$
\begin{gathered}
\mathrm{Ca}(\mathrm{OCl})_{2}+2\left(\mathrm{H}_{2} \mathrm{O}\right) \leftrightarrow 2 \mathrm{HOCl}+\mathrm{Ca}(\mathrm{OH})_{2} \\
\frac{2 \mathrm{HOCl} \rightarrow 2 \mathrm{HCl}+2 \mathrm{O}_{2}}{\mathrm{Ca}(\mathrm{OCl})_{2} 2 \mathrm{H}_{2} \rightarrow \mathrm{Ca}(\mathrm{OH})_{2}+2 \mathrm{H}_{2} \mathrm{O}+2 \mathrm{O}_{2}}
\end{gathered}
$$

Chlorine reacts with water to produce $\mathrm{Ca}(\mathrm{OH})_{2}$ (which is alkaline) and $\mathrm{HOCl}$, where this $\mathrm{HOCl}$ will form oxygen atoms. The more $\mathrm{HOCl}$ that is formed, the more oxygen atoms will be released so that the disinfectant will increase.

\begin{tabular}{|c|c|c|c|c|c|c|}
\hline \multirow{3}{*}{ Chlorine (\%) } & \multicolumn{3}{|c|}{ Bacillus stearothermophilus } & \multicolumn{3}{|c|}{ Bacillus subtilis } \\
\hline & \multicolumn{3}{|c|}{$\begin{array}{l}\text { Total colony number } \\
\left(1 \times 10^{5} \mathrm{CFU} / \mathrm{mL}\right)\end{array}$} & \multicolumn{3}{|c|}{$\begin{array}{c}\text { Total colony number } \\
\left(1 \times 10^{5} \mathrm{CFU} / \mathrm{mL}\right)\end{array}$} \\
\hline & $15^{\prime}$ & $30^{\prime}$ & $45^{\prime}$ & $15^{\prime}$ & $30^{\prime}$ & $45^{\prime}$ \\
\hline 0.01 & 5 & 5 & 5 & 3 & 3 & 5 \\
\hline 0.02 & 3 & 3 & 3 & 2 & 2 & 2 \\
\hline 0.03 & 2 & 2 & 0 & 1 & 0 & 0 \\
\hline
\end{tabular}

Table 8. Minimum bactericidal concentration test result 
However, the $\mathrm{pH}$ of the solution needs to be considered so that chlorine disinfection is more optimal (Rohim, 2006).

Determination of the optimum dose of chlorine for water samples based on the chlorination breakpoint curve. The advantage of achieving a breakpoint is that the ammonium compound is completely oxidized (Joko, 2010), completely kills pathogenic bacteria, and prevents algae growth. The contact time is thought to be the most important factor in the disinfection process. The longer the contact time between the disinfectant and microbes in the water, the greater the killing power (Budiyono and Sumardiono, 2013).

Free chlorine damages the membrane of the bacterial cell, this causes the cell to lose its permeability (ability to penetrate) and damage other cell functions (Figure 6). Chlorine exposure causes leakage of protein, RNA, and DNA. Damage to permeability is the cause of the destruction of bacterial spores by chlorine (Bitton, in Said, 2007). Chlorine also destroys bacterial nucleic acids, as well as enzymes. One result of the reduction in catalyst activity is inhibition by the accumulation of hydrogen peroxide. How chlorine works against viruses depends on the type of virus (Busyairi, 2016).

The macroscopic (A) and microscopic (B) form of the bacterial cells forming the lender biofilm, the size of the colony, and the bacterial cells were not on a proper scale, because the image had automatically undergone a digital enlargement.
The application of active chlorine was able to reduce the MPN of Bacillus subtilis and Bacillus stearothermophilus according to the quality standards of hospital wastewater.

\section{CONCLUSIONS}

There were no differences in the duration of contact time and the dose of chlorine as a disinfectant on the number of Bacillus subtilis and Bacillus stearothermophilus in the medical waste recycling process with a p-value of 0.377 . The percentage reduction in the number of Bacillus subtilis and Bacillus stearothermophilus before and after treatment was $99.99 \%$ based on 4 positive controls. The duration of contact time and the effective dose used in the recycling process of medical waste in RS Santo Yusuf Boromeus is $0.03 \%$ with a contact time of 45 minutes.

The government needs to conduct a review related to the recommended ideal dosage in the surface disinfection process, so that it would not cause a potential risk to humans or the environment.

\section{Acknowledgements}

This study was financially supported by The Research and Community Service Unit of Bandung Health Polytechnic, Ministry of Health, Indonesia scheme.

A

B

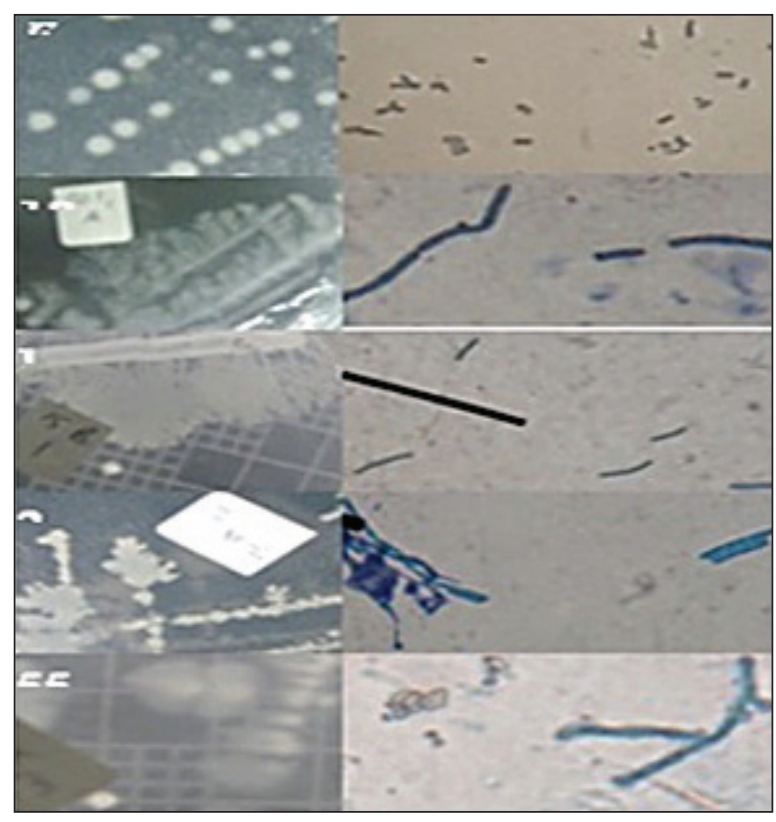

Figure 6. Mechanism of bacterial damage by chlorine 


\section{REFERENCES}

1. Adisasmito, W. 2009. Hospital environmental management system. Raja Grafindo Persada, Jakarta.

2. Akter, N., Trankler, J. 2003. An analysis of possible scenarios of medical waste management in Bangladesh. Management of environment quality. An International Journal, 14(2), 242-255.

3. Akum, F. A. 2014. An assessment of medical waste management in bawku presbyterian hospital of the upper East Region of Ghana. Merit Research Journal of Environmental Science and Toxicology, 2(2), 27-38.

4. Al-Khatib, I. A. 2013. Problems of management of medical solid waste at primary health care centres in the Palestinian Territory and their remedial measures. Eastern Mediterranean Health Journal, 19(3), 152-158.

5. Ali, M., Wenping W., Nawaz C., Yong G. 2017. Hospital waste management in developing countries: A mini review. Waste Management and Research, 35(6), 581-592.

6. Almuneef, M., Memish, Z. A. 2003. Effective medical waste management: It can be done. American Journal of Infection Control, 31(3), 188-192.

7. Anam, H. 2004. The effect of water storage time against residual chlorine in water distribution at PDAM Giri Menang Mataram. Ph.D. Thesis, Polekkes Kemenkes Mataram.

8. Arikunto, S. 2010. Research procedure: a practical approach. Rineke Cipta, Jakarta.

9. Aziz, T., Dwi Y.P., Lola R. 2013. The effect of the addition of alum $\mathrm{Al}_{2}\left(\mathrm{SO}_{4}\right)_{3}$ and chlorine $\mathrm{Ca}(\mathrm{OCl})_{2}$ on the physical and chemical characteristics of Lambidaro River water. Jurnal Teknik Kimia, 3(19), 55-65.

10. Bokhoree, C., Y. Beeharry., T. Makoondlall-Chadee, T. Doobah., N. Soomary. 2014. Assessment of environmental and health risks associated with the management of medical waste in mauritius. Procedia - Social and Behavioral Sciences. 9, 36-41.

11. Budiyono., Sumardiono. 2013). Water treatment engineering. Graha Ilmu, Yogyakarta.

12. Busyairi, M., Dewi, Y.P., Widodo, D.I. 2016. Effectiveness of chlorine in chlorination process on decreasing coliform bacteria from wastewater at X Hospital Samarinda. Journal of Humans and the Environment. 23 (2), 156-162.

13. Chartier, Y., Jorge E., Ute P., Annette P., Philip., Ruth S., William T., Susan W., Raki Z. 2014. Safe management of wastes from health-care activities. WHO, Geneva.

14. Cheng, Y. W., Li, K., Sung F. C. 2010. Medical waste generation in selected clinical facilities in Taiwan. Waste Management. 30(8), 1690-1695.

15. Emilia, A. U., Julius, N. F., Gabriel, G. 2015. Solid medical waste management in Africa. African Journal of Environmental Science and Technology, 9(3), 244-254.

16. Gunawan, H. 2019. Implementation of hazardous waste management from health service facilities (seminar and workshop on medical hazardous waste management). Environmental office of Banten province, Indonesia.

17. Gupta, S., Boojh, R. 2006. Report: Biomedical waste management practices at Balrampur Hospital, Lucknow, India. Waste Management and Research, 24(6), 584-591.

18. Handayani, K., Sugeng A. 2015. Measurement of residual chlorine levels before and after swimming pool water use at Water Park Surya Yudha, Banjarnegara Regency. Keslingmas 35(1), 57-59.

19. Hamid, A. et al. 2013. Striving for scientific management of medical waste. International Journal of Development and Sustainability. 2(3), 1858- 1866.

20. Joko. T. 2010. Drinking Water Supply System Production Unit. Graha Ilmu, Yogyakarta.

21. Manga, V. E., Osric T.F., Linus A.M., Ryan W. 2011. Health care waste management in Cameroon : A case study from the Southwestern Region. Resources, Conservation and Recycling, 57, 108-116.

22. Mantzaras, G., Voudrias, E. A. 2017. An optimization model for collection, haul, transfer, treatment and disposal of infectious medical waste: Application to a Greek region. Waste Management. 69, 518-534.

23. MenKLHK RI. 2015. Regulation of the Minister of Environment and Forestry of the Republic of Indonesia No P.56 / MENLHK-Setjen / 2015 concerning Procedures and Technical Requirements for Management of Hazardous and Toxic Waste from Health Facilities.

24. Notoatmodjo, S. 2014. Health Methodology. Rineka Cipta, Jakarta.

25. Ojuolape, O. T., Afon, A. O. 2016. Solid waste characterization in private health institutions : empirica; evidence from ibadan metropolis. Management Research and Practice, 8(1), 50-60.

26. Omar, D., Nurshahida, S., Karuppannan, S.A.L. 2012. Clinical waste management in District Hospitals of Tumpat, Batu Pahat and Taiping. Procedia - Social and Behavioral Sciences. 68, 134-145.

27. Republic of Indonesia Government Regulation No. 101 of 2014. Concerning Management of Hazardous and Toxic Waste.

28. Regulation of the Minister of Environment of the Republic of Indonesia No. 14 of 2013 concerning Symbols and Labels of Hazardous and Toxic Waste Materials.

29. Riyanto. 2013. Hazardous and Toxic Waste. Deepublish, Yogyakarta. 
30. Rohim, M. 2006. Analysis of implementation simple chlorination method to bacteriological quality of PMA Water. Experimental study in Boawae Flores NTT Region. Ph.D. Thesis, Diponegoro University, Semarang.

31. Sabri, L., Hastono, S. P. 2014. Health Statistics. PT Raja Grafindo Perkasa, Jakarta.

32. Sari, D.R. 2018. Factors related to the presence of residual chlorine in the cileng water supply distribution network of PDAM Lawu Tirta Magetan. Ph.D. Thesis, Stikes Bhakti Husada, Madiun.

33. Sinta S.S. 2020. Hazardous waste handling (COVID-19), capacity analysis and alternative solutions,
Bappenas Webinar and the ITB Environmental Engineering Alumni Association 28 April 2020. Ministry of Environment and Forestry, Jakarta.

34. Sugiyono. 2010. Quantitative research methods, qualitative, and R \& D. Alfabeta, Bandung.

35. Sumampouw, O.J. 2015. Dictate of environmental pollution. Researchgate, Manado.

36. Wulandari, P., Kusnoputranto, H. 2015. Medical waste management and minimization efforts at public hospital. case study: public hospital in East Jakarta, Indonesia. Jurnal Kesehatan Masyarakat (Journal of Public Health), 9(2), 77-84. 